\title{
WELAS DIRI UNTUK MAHASISWA
}

\author{
Sandra Handayani Sutanto ${ }^{1}$, Jesslyn Tanmas ${ }^{2}$ \\ ${ }^{1}$ Universita Pelita Harapan, Karawaci Tangerang \\ ${ }^{2}$ Universitas Multimedia Nusantara, Gading Serpong Tangerang \\ sandra.sutanto@uph.edu, jetanmas12@gmail.com
}

\begin{abstract}
Abstrak
Tugas perkembangan emerging adult yang berusia 18-25 tahun adalah mengeksplorasi diri dalam pekerjaan, percintaan dan pandangan dunia. Di tengah eskplorasi tersebut, seringkali mengalami hambatan yang berakhir dengan kebencian terhadap diri sendiri, namun bisa diatasi dengan menumbuhkan welas diri, dengan cara berbuat baik dan penuh pemahaman terhadap diri sendiri, melihat pengalaman yang dialami sebagai bagian besar dari pengalaman umat manusia, dan mengijinkan diri untuk mengalami pengalaman yang menyakitkan apa adanya, tanpa menghindar dan lari dari masalah. Pengabdian kepada masyarakat dilakukan dengan memberikan seminar kepada 29 orang mahasiswa UMN. Seminar Welas Diri dilakukan dalam dua bagian. Bagian pertama berisi paparan informasi mengenai kebencian terhadap diri sendiri dan konsep welas diri yang harus dimiliki oleh mahasiswa. Bagian kedua dilakukan dengan mencoba beberapa kegiatan yang bisa dilakukan untuk mengurangi kebencian terhadap diri sendiri.
\end{abstract}

Kata Kunci : welas diri, emerging adul, self-compassion, psikologi positif; mahasiswa

\section{PENDAHULUAN}

Salah satu tahapan perkembangan yang akan dilalui oleh manusia adalah emerging adult. Secara singkat, emerging adult adalah masa transisi antara remaja dan masa dewasa, dalam rentang usia 18-25 tahun. Tugas perkembangan emerging adult agak berbeda dengan remaja, yaitu mengeksplorasi identitas yang berhubungan dengan aspek pekerjaan, percintaan dan pandangan akan dunia (Arnett, 2007). Pada masa ini, emerging adult juga mengalami dilema, pada satu sisi mereka belum siap sepenuhnya untuk mengambil seluruh tugas dan tanggung jawab untuk menjadi dewasa sepenuhnya, namun di sisi lain dunia dan lingkungan di sekeliling mereka memiliki harapan yang tinggi bahwa emerging adult, dalam konteks seminar ini adalah mahasiswa akan memenuhi tugas sebagai individu yang beranjak dewasa.

Tuntutan dan keperluan untuk memenuhi tahapan dewasa memang tidak mudah. Dalam perkuliahan, misalnya dosen mengharapkan capaian tertentu atau tenggat waktu tertentu untuk pengerjaan tugas dan perkuliahan. Jika hal tersebut tidak bisa dipenuhi, maka hal tersebut mendatangkan kekecewan bagi individu yang mengalaminya. Horney (dalam Feist, Feist \& Roberts, 2013) menyatakan bahwa individu mengalami konflik intrapsikis dalam upayanya mengembangkan kepribadian. Konflik intrapsikis berasal dari pengalaman individu yang lama-kelamaan menjadi belief system guna mempertahankan eksistensi mereka. Konflik intrapsikis tersebut berkembang dengan cara menciptakan hal yang ideal untuk diri mereka (idealized self-image) dan membenci diri

$$
\text { Pendidikan }
$$


mereka (self hatred), berikut kecenderungan irasional yang cukup kuat untuk memandang rendah diri yang sebenarnya.

Idealized self image didefinisikan sebagai usaha individu untuk menyelesaikan konflik dengan membuat gambaran yang ideal mengenai diri mereka. Hal ideal tersebut akan memacu mereka untuk mengembangkan diri mereka dan semakin asing dengan diri mereka yang sebenarnya. Singkatnya mereka berupaya menjadikan hal yang ideal menjadi bagian dari diri mereka, terlepas apakah mereka mampu atau tidak mampu untuk mewujudkannya.

Horney menyatakan bahwa individu yang terus berusaha untuk mencapai kemuliaan bagi diri mereka pada akhirnya tidak akan pernah bahagia. Proses menyadari bahwa keinginan dan apa yang mereka miliki tidak akan memuaskan keinginan untuk mencapai idealized self image, berujung dengan kebcndian individu yang memandang rendah diri mereka. Horney menyebutkan enam cara yang digunakan untuk mengekspresikan kebencian terhadap diri mereka. Cara yang pertama adalah dengan relentless demands on the self, membuat tuntutan terhadap diri mereka dan tidak pernah berhenti walaupun sudah mencapai kesuksesan pada level tertentu. Cara kedua adalah merciless selfaccusation, mencaci diri mereka secara konstan. Cara ketiga, dengan melakukan self-contempt, yang diekspresikan dengan cara mengecilkan, meragukan, mendiskreditkan dan membuat diri sendiri sebagai lelucon. Cara keempat yaitu self-frustration, dengan membelenggu diri untuk menikmati berbagai hal yang menyenangkan, misalnya 'saya tidak berhak untuk mengenakan baju yang bagus karena masih banyak orang lain yang menjadi gelandangan.; Cara yang kelima dimanifestasikan dengan self-torment, upaya untuk memunculkan rasa sakit atau penderitaan terhadap diri mereka. Cara yang terakhir adalah dengan self-destructive actions and impulses, melibatkan kondisi fisik dan psikis, disadari atau tidak disadari, akut atau kronis, segala tindakan atau hanya dalam imajinasi usaha untuk merusak diri sendiri, misalnya dengan mengebut melebihi kecepatan yang diperbolehkan, bekerja terlalu keras dan bunuh diri. Fenomena yang bisa diamati adalah dengan beberapa kejadian bunuh diri pada mahasiswa, misalnya yang dialami JA di tahun 2016 (Tristiawati, 2016) dan A (Bahar, 2018). Kedua mahasiswa tersebut merupakan mahasiswa di perguruan tinggi yang sama, dengan angkatan berbeda, yang mengambil cara ekstrim untuk mengatasi masalahnya.

Salah satu cara untuk mengurangi kebencian terhadap diri sendiri adalah dengan menumbuhkan self-compassion atau belas kasihan terhadap diri sendiri, welas diri. Neff (2003) mendefinisikan welas diri sebagai rasa belas kasihan yang diperluas untuk diri sendiri ketika penderitaan terjadi atau ketika lingkungan eskternal menjadi sulit untuk dihadapi. Neff (2003b) menambahkan bahwa welas diri merupakan kemampuan individu untuk peka dengan penderitaan yang sedang dialami, tidak menghindar, serta adanya keinginan untuk mengurangi penderitaan yang dirasakan.

Welas diri memiliki tiga buah dimensi yang saling terikat dengan dimensi yang berkebalikan. Dimensi yang pertama adalah self kindness, yaitu upaya untuk memperlakukan diri dengan kebaikan dan mengurangi penderitaan yang dialami. Berkebalikan dengan self kindness adalah selfjudgment yang menghakimi diri saat mengalami kesalahan atau kekurangan. Dimensi yang kedua adalah common humanity, mencoba melihat pengalaman yang dialami sebagai bagian pengalaman umat manusia dan menyadari bahwa hidup ini tidaklah sempurna. Berkebalikan dengan common humanity, adalah isolation, merasa dirinya adalah satu-satunya yang mengalami hal tersebut di dunia. Dimensi yang ketiga adalah mindfulness, merasakan sakit sebagaimana apa adanya, tidak menekan atau melarikan diri dari perasaan sakit. Berkebalikan dengan mindfulness adalah overidentification, usaha melarikan diri dari kegagalan atau penderitaan yang dialami.

Ketiga hal dalam welas diri, yaitu self kindness, common humanity dan mindfulness-- ini bisa dilatih dengan berbagai macam cara. Neff dan Dahm (2015) menganjurkan untuk melatih welas diri dengan mengucapkan frase yang sama berulangulang terhadap diri sendiri. Aktivitas yang lain dengan melibatkan menuliskan surat kepada diri sendiri dengan mengambil perspektif seorang teman yang akan melihat ketidakmampuan yang berujung pada kecenderungan untuk menghakimi diri sendiri (Neff, 2019). Surat tersebut juga menyatakan pendapat apa yang akan diberikan oleh teman

$$
\text { Pendidikan }
$$


tersebut, serta saran perubahan yang diharapkan dari individu tersebut.

Welas diri mendatangkan manfaat yang cukup positif bagi individu yang melakukannya. Neff dan Dahm (2015) menyebutkan bahwa welas diri memampukan seseorang untuk sedikit menderita, membantu individu untuk berkembang, dan mengurangi efek negatif pada fungsi emosional seseorang. Welas diri juga mengurangi kecemasan dan depresi (Blatt, 1995). Tidak hanya mengurangi efek negatif, welas diri juga meningkatkan perilaku hidup sehat termasuk tetap bertekun terhadap diet (Adams \& Leary, 2007), mengurangi kebiasaan merokok (Kelly, Zuroff, Foa, \& Gilbert, 2009), mencari pertolongan medis saat diperlukan (Terry \& Leary, 2011) dan berolahraga (Magnus, Kowalski, \& McHugh, 2010). Hasil penelitian juga menyatakan bahwa kesepian yang dialami oleh mahasiswa bisa diatasi dengan membiasakan welas diri (Sugianto, Sutanto, \& Suwartono, 2020).

Dengan begitu banyaknya manfaat yang dihasilkan oleh welas diri, maka wawasan dan pengaplikasian welas diri menjadi hal yang krusial untuk dilakukan bagi mahasiswa yang berada dalam tahapan emerging adult. Hal ini disadari dan menjadi concern bagi penulis dan salah satu mahasiswa program studi Public Relation di Universitas Multimedia Nusantara yang bekerja sama dengen penulis untuk mengadakan kegiatan seminar mengenai welas diri. Diharapkan dengan kegiatan tersebut, mahasiswa menyadari bahwa sekalipun mereka mempunyai banyak sisi negatif dan dalam kondisi penuh tekanan, tetapi mereka juga mempunyai sisi positif yang bisa dikembangkan.. Oleh karena itu seminar ini diharapkan akan membuat mereka mengurangi kebencian terhadap diri sendiri (self-hatred), lebih memiliki kesadaran akan pentingnya self compassion bagi mereka dan mampu melakukannya dalam kehidupan sehari-hari.

\section{METODE}

Seminar Welas Diri dilakukan dalam 2 bagian acara. Bagian pertama berupa pemaparan mengenai realita yang dialami oleh mahasiswa terutama yang berkaitan dengan kebencian kepada diri sendiri. Setelah itu dilanjutkan dengan membahas mengenai Welas Diri dan semua dimensi- dimensinya. Sesi pertama ini diakhiri dengan Tanya jawab dengan seluruh peserta.

Bagian kedua berupa aktifitas yang dilakukan oleh seluruh peserta. Aktifitas yang dimaksud terdiri dari dua bagian. kegiatan pertama dengan mengucapkan beberapa kalimat yang ditujukan sebagai kebaikan kepada diri sendiri. Pengulangan kalimat dilakukan dengan berdiri dengan tangan kanan memegang bagian dada kiri. Kegiatan kedua dilakukan dengan membuat surat kepada diri sendiri dari perspektif salah seorang teman. Peserta diberikan waktu untuk memvisualisasikan teman yang sedang berbicara, memberikan saran lalu menuliskan visualisasi tersebut dalam bentuk surat, dengan amplop yang ditujukan pada diri sendiri. Saat mahasiswa menuliskan surat, lagu-lagu yang bertemakan welas diri juga dimainkan. Sebelum memasuki bagian pertama dan sesudah aktifitas di bagian kedua, semua peserta seminar mengisi pre-test dan post-test berupa skala Welas Diri dari Neff (2019).

\section{HASIL DAN PEMBAHASAN}

\section{Hasil kegiatan}

Peserta seminar terlihat antusias dengan acara ini. Sebagian besar datang lebih awal dari waktu yang ditentukan. Setelah hampir semua peserta berkumpul, panitia acara membagikan kuesioner pre-test yang perlu diisi oleh peserta, sembari mendengarkan music performance.

Acara dimulai dengan sambutan dari Kepala Program Studi Public Relation UMN. Urgensi dan tujuan acara dan pre-event dijelaskan lebih lanjut oleh Sdri Jesslyn, sebagai ketua panitia kegiatan. Acara dilanjutkan dengan sesi seminar yang dibagi menjadi 2 bagian, yaitu bagian pemaparan dan sesi aktifitas.

Pada sesi pertama dipaparkan mengenai fenomena yang terjadi di kalangan mahasiswa mengenai self hatred. Pada titik yang ekstrim, kebencian pada diri sendiri bisa muncul dalam bentuk bunuh diri/menyudahi diri, depresi atau perilaku lain yang tanpa sadar ditujukan kepada diri sendiri dalam bentuk kebencian, misalnya : Saya bodoh! Pantas saja dosen-dosen tidak menyukai saya, Welas diri berarti memperlakukan diri dengan penuh kebaikan, menyadari bahwa pengalaman yang dialami adalah bagian dari pengalaman yang dialami

$$
\text { Pendidikan }
$$


oleh umat manusia serta melakukan mindfulness, kesadaran penuh akan apa yang dilakukan dan tidak melarikan diri dari masalah atau tantangan hidup.

Untuk menghentikan kebencian pada diri sendiri, maka kita perlu untuk membiasakan welas diri. Welas diri juga memiliki banyak kegunaan dalam hidup, termasuk membantu mengatasi peristiwa negatif yang dialami oleh manusia. Manfaat welas diri juga telah diteliti dan terbukti bermanfaat untuk kesehatan fisik dan mental. Acara tanya jawab dilakukan setelah pemaparan welas diri. Dalam sesi tanya jawab ini mahasiswa bisa membagikan pengalamannya saat mengalami kebencian terhadap diri sendiri.

Welas diri perlu dilatih dan dibiasakan dalam hidup. Untuk membantu mahasiswa mempraktikkan welas diri, maka pada sesi kedua, peserta diberikan kesempatan untuk melakukan aktifitas welas diri. Kegiatan yang pertama adalah dengan memberikan kata-kata positif terhadap diri sendiri dengan cara berdiri, dengan tangan kanan memegang dada kiri dan menirukan kalimat yang diucapkan oleh pembicara. Aktifitas yang kedua adalah membuat surat. yang ditujukan kepada dirinya sendiri. Surat tersebut dibuat dengan menggunakan perspektif dari orang lain yang akan memberikan penilaian mengenai kondisi peserta secara jujur dan penghargaan terhadap semua hal yang telah dilakukan oleh peserta selama ini. Setelah selesai membuat surat, peserta diminta untuk memasukan surat tersebut ke dalam amplop untuk dibawa pulang dan dibaca pada waktu tertentu. Dari hasil observasi pembicara dan panitia, beberapa peserta tampak termenung cukup lama sewaktu membuat surat tersebut. Ada pula yang terlihat terharu dalam pembuatan surat. Setelah acara seminar, ada dua hingga tiga orang yang menginginkan waktu lebih untuk bercakap-cakap dan menceritakan mengenai pengalaman pribadinya terutama yang berkaitan dengan membenci diri dan proses yang dialami untuk melakukan welas diri, termasuk upaya untuk pergi konseling agar dapat mengatasi hal yang telah mereka alami.

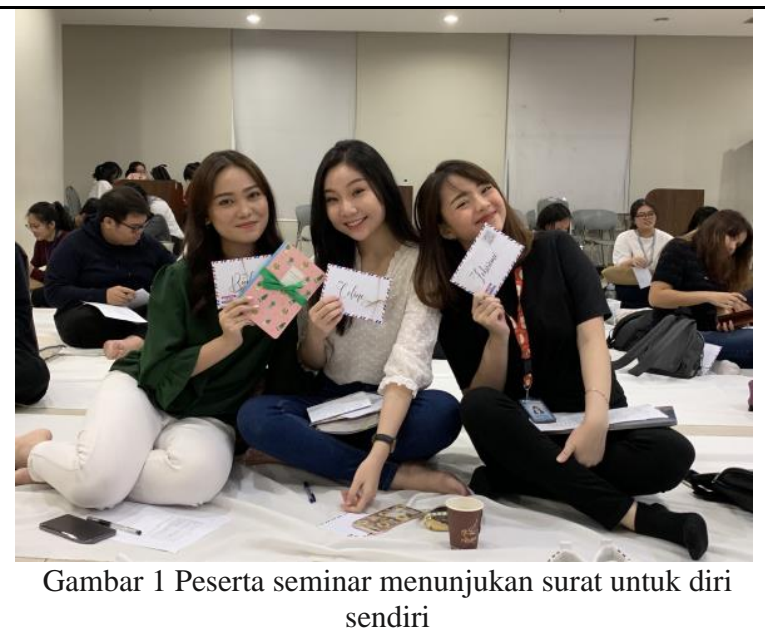

Tujuan dari kegiatan ini adalah memberikan wawasan mengenai welas diri kepada peserta, membantu mahasiswa untuk memiliki rasa welas diri dalam hidupnya. Hasil dari pre-test dan post-test yang dilakukan dalam kegiatan menunjukan bahwa ada peningkatan rata-rata welas diri yang dimiliki oleh peserta sebesar 11,17 poin (lihat tabel 1).

Tabel. 2 Perbedaan Pre-Post Test (29 Peserta)

\begin{tabular}{llll} 
& Skor Min & Skor Max & Rata-rata \\
\hline Pre-Test & 51 & 122 & 72.03 \\
\hline Post-Test & 56 & 126 & 83.20 \\
\hline
\end{tabular}

\section{Evaluasi kegiatan}

Sebelum foto bersama, peserta melakukan evaluasi kegiatan. Tanmas (2019) telah melakuakn evaluasi kegiatan yang lebih menyeluruh untuk aspek acara seminar. Aspek yang diukur meliputi relevansi topik pada mahasiswa, penguasaan materi, kejelasan pembicara dalam menyajikan materi hingga interaksi yang terbangun antara pembicara dengan peserta. 


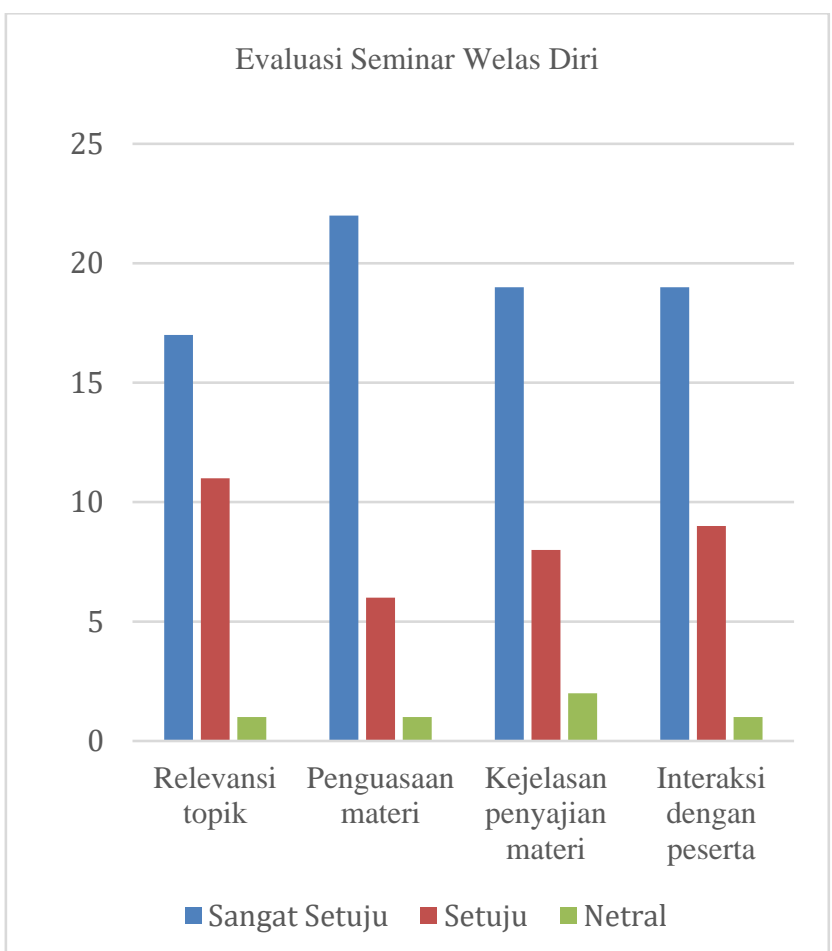

Grafik 1. Evaluasi seminar Welas Diri

Dari hasil evaluasi tersebut, bisa disimpulkan bahwa seminar ini relevan dengan kondisi yang dialami oleh mahasiswa. Dari sisi pembicara, kemampuan menguasai materi juga terbilang baik, jelas dalam membawakan materi dan mampu melakukan interaksi dengan peserta.

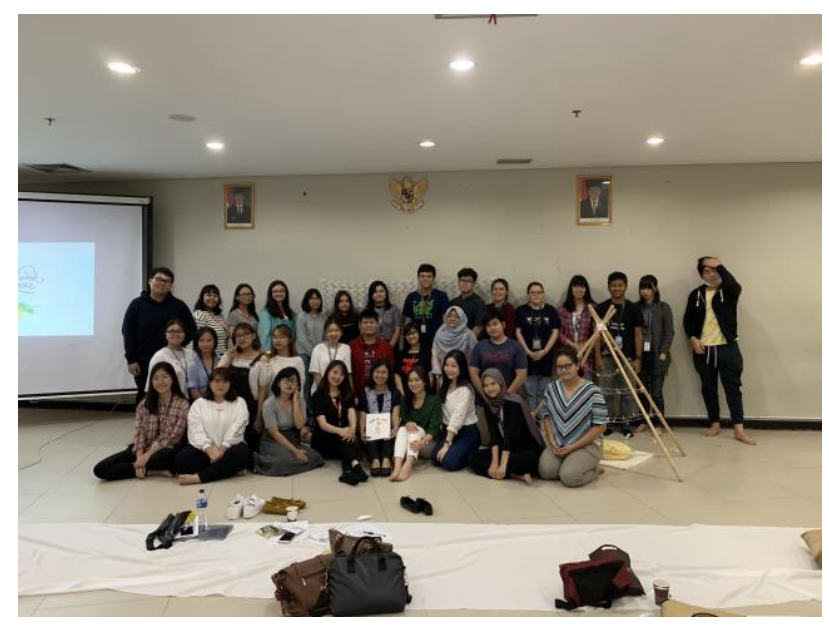

Gambar 2 Foto dengan seluruh peserta

\section{KESIMPULAN}

Seminar welas diri yang diikuti oleh mahasiswa ini dapat memberikan pengetahuan dan juga pemahaman yang meningkat dari peserta mengenai welas diri. Pemahaman dan kesadaran yang tepat mengenai welas diri akan diharapkan mengurangi kebencian terhadap diri sendiri yang dialami oleh mahasiswa dan bersikap lebih baik terhadap dirinya.

Untuk kegiatan berikutnya perlu menyediakan waktu yang lebih banyak, atau personil dan konselor yang siap untuk menampung refleksi diri atau pengalaman peserta ketika menceritakan pengalaman membenci diri atau bertanya lebih lanjut proses memahami diri dan melakukan welas diri.

\section{UCAPAN TERIMAKASIH (Bila ada)}

Ucapan terimakasih disampaikan kepada pimpinan Universitas Pelita Harapan, Lembaga Penelitian dan Pengabdian Masyarakat Universitas Pelita Harapan, Kepala Program Studi Public Relation Universitas Multimedia Nusantara serta semua panitia dan mahasiswa yang membantu pelaksanaan kegiatan seminar.

\section{REFERENSI}

Adams, C.E., \& Leary, M.R. (2007). Promoting self-compassionate attitude toward eating among restrictive and guilty eaters. Journal of Social and Clinical Psychology, 26, 1120-1144.

Arnett, J. J. (2007). Emerging adulthood: What is it, and what is it good for?. Child development perspectives, 1(2), 68-73.

Bahar, A. (28 January 2019). Kasus bunuh diri mahasiswa tangerang jadi teguran supaya kita lebih perhatian sama teman dan peduli kesehatan mental. Hai. Diunduh dari https://hai.grid.id/read/071618183/kasus-bunuhdiri-mahasiswa-tangerang-jadi-teguran-supaya-kitalebih-perhatian-sama-teman-dan-peduli-kesehatan$\underline{\text { mental?page }=\text { all }}$ 
Blatt,S.J. (1995). Representational structures in psychopathology. In D. Cichetti \& S. Toth (Eds.), Rochester symposium on developmental psychopathology : Emotion, cognition, and representation, Vol. 6 (pp.1-34). Rochester, NY : University of Rochester Press.

Feist, J., Feist, G.J., \& Roberts, T. (2013). Theories of personality (8th ed.). New York: McGraw-Hill.

Kelly, A.C., Zuroff, D.C., Foa, C.L., \& Gilbert, P. (2009). Who benefits from training to self compassionate self regulation? A study of smoking reduction. Journal of Social and Clinical Psychology, 29, 727-755.

Magnus,C., Kowalski, K., \& McHugh, T. (2010). The role of self-compassion in women's self determined motives to exercise and exercise-related outcomes. Self and Identity, 9, 363-382.

Neff, K.D. (2003). Self-compassion : An alternative conceptualization of a healthy attitude toward oneself. Self and Identity, 2, 85-101. Doi : 10.1080/15298860390129863.

Neff, K.D. (2003b). The development and validation of a scale to measure self compassion. Self and Identity, 2, 223-250. Doi : $10.1080 / 15298860390209035$.

Neff, K.D. (2011). Self-compassion. New York : William Morrow.
Neff, K.D., \& Beretvas, S.N. (2012). The role of self-compassion in romantic relationships. Self and Identity. DOI: 10.1080/15298868.2011.639548.

Neff, K.D., \& Dahm, K.A. (2015). Handbook of mindfulness and self regulation. Texas : University of Texas.

Neff, K.D. (2019). Self-compassion. Diunduh dari https://self-compassion.org/exercise-3exploring-self-compassion-writing/

Sugianto, D., Sutanto, S.H. \& Suwartono, C. (2020). Self compassion as a way to embrace loneliness in university students. Psikodimensia, 19(1), 122-131.

Tanmas, J. (2019). Manajemen special event 'Note to Self' sebagai solusi untuk meningkatkan awareness mahasiswa Universitas Multimedia Nusantara. (Skripsi). Universitas Multimedia Nusantara, Tangerang, Indonesia.

Terry, M.L., \& Leary, M.R. (2011). Selfcompassion, self-regulation, and health. Self and Identity, 10, 352-362.

Tristiawati, P. (18 May 2016). Mahasiswa tewas gantung diri di kamar kos Gading Serpong. Liputan 6.6 Diunduh dari https://www.liputan6.com/news/read/2510046/maha siswa-tewas-gantung-diri-di-kamar-kos-gadingserpong 